\title{
Gender Taboo di Media Sosial: Analisis Penerimaan terhadap 'Perlawanan' Danilla Riyadi di Instagram dan Youtube
}

\author{
Clara Ocktarida Sutisna ${ }^{1}$, Nanang Krisdinanto ${ }^{2 *}$, Brigitta Revia S.F ${ }^{3}$ \\ ${ }^{1,2,3}$ Universitas Katolik Widya Mandala Surabaya \\ "Email: nangkris@ukwms.ac.id
}

\begin{abstract}
Abstrak
Penelitian ini berfokus pada dinamika penerimaan perempuan terhadap isu gender taboo di media sosial pada akun Instagram dan Youtube Danilla Riyadi. Melalui konten media sosialnya, Danilla dikenali sebagai penyanyi yang perilakunya di depan kamera sering memicu kontroversi seperti merokok, minum alkohol, mempertontonkan tato, atau mengucapkan kata-kata jorok. Dalam konteks gender, apa yang dilakukannya secara implisit bisa dilihat sebagai bentuk perlawanannya terhadap gender taboo yang mengungkung perempuan. Penelitian ini melihat bagaimana audiens menerima atau meresepsi konten dengan pesan sensitif seperti ini. Peneliti menggunakan pendekatan kualitatif, tipe deskriptif, serta metode analisis penerimaan yang dikembangkan Stuart Hall. Data diperoleh melalui wawancara mendalam kepada perempuan penonton akun Danilla Riyadi. Temuan menunjukkan adanya dinamika atau keragaman posisi penerimaan subjek penelitian terhadap konten Danilla Riyadi (dominant, negotiated, opposition). Di satu sisi, konten Danilla diterima sebagai pesan yang penolakan terhadap gender taboo. Namun di sisi lain, konten diterima sebagai sesuatu yang merugikan perempuan, karena ekspresi Danilla dianggap tidak pantas bagi perempuan.
\end{abstract}

Kata Kunci: Analisis penerimaan, tabu gender, media sosial, Danilla Riyadi

\begin{abstract}
This study focuses on the dynamics of women's acceptance of taboo gender issues on social media on Danilla Riyadi's Instagram and Youtube accounts. Through her social media content, Danilla is recognized as a singer whose behavior in front of the camera often triggers controversy such as smoking, drinking alcohol, showing tattoos, or saying obscene words. In the context of gender, what he does implicitly can be seen as a form of resistance to the gender taboo that confines women. This research looks at how the audience receives or perceives content with sensitive messages like this. The researcher used a qualitative approach, descriptive type, and the acceptance analysis method developed by Stuart Hall. The data was obtained through in-depth interviews with female viewers of Danilla Riyadi's account. The findings show that there are dynamics or diversity in the position of acceptance of the research subject towards Danilla Riyadi's content (dominant, negotiated, opposition). On the one hand, Danilla's content is accepted as a message that rejects gender taboo. But on the other hand, content is accepted as something that is detrimental to women, because Danilla's expression was deemed inappropriate for women.
\end{abstract}

Keywords: Reception analysis, gender taboo, social media, Danilla Riyadi

\section{PENDAHULUAN}

Penelitian ini berfokus pada dinamika diseputar penerimaan perempuan terhadap isu tabu gender (gender taboo) di media sosial. Gender taboo di sini, mengutip Allan \& Burridge (2006), merupakan larangan atas perilaku yang dianggap bisa mempengaruhi kehidupan sehari-hari. Setiap kebudayaan mempunyai standar perilaku atau praktik sosial apa yang dianggap tabu dan standar tersebut berbeda dari kebudayaan yang satu dengan lainnya. Tabu 
dapat disebabkan oleh kendala sosial yang dirasakan individu dalam masyarakat, yang jika dilanggar dapat menyebabkan ketidaknyamanan dan bahaya pada individu maupun kelompok. Dalam konteks gender, persoalan tabu ini terkait apa yang dikatakan Samovar \& Richard (dalam Mulyana 2009) bahwa stereotype merupakan persepsi atau kepercayaan yang dianut oleh kelompok atau individu dengan merujuk pada sikap yang sudah dibentuk lebih dulu. Sementara budaya masyarakat negara berkembang cenderung memosisikan perempuan sebagai warga atau kelompok masyarakat yang tersubordinasi dengan berbagai label negatif terhadap dirinya (Handayani 2012).

Levit (1998) menyebut gender sebagai sesuatu yang dikonstruksi yang membuat orang memercayai bahwa laki-laki dan perempuan memang berbeda dalam hal kemampuan, ketertarikan, dan keinginan. Nilai-nilai budaya patriarki telah membatasi pandangan dan pilihan di antara perempuan dan laki-laki. Gender juga merupakan istilah yang digunakan untuk meliputi ekspetasi sosial yang berhubungan dengan feminitas dan maskulinitas. Lips (2017) menulis, setiap budaya berbeda antara satu dengan yang lain, serta dipengaruhi peraturan-peraturan yang berbeda untuk memisahkan feminitas dan maskulinitas. Hal ini merupakan bukti kuat bahwa gender adalah sesuatu yang berasal dari konstruksi sosial, yang diantaranya bisa dilihat dari berubahnya aturan-aturan sosial dari waktu ke waktu dan pada budaya tertentu.

Tabu sosial yang berlaku pada perempuan (gender taboo) diantaranya terlihat pada praktik-praktik sosial tertentu seperti merokok, tato, atau konsumsi alkohol. Dalam konteks masyarakat patriarki seperti Indonesia, rokok secara umum misalnya masih dianggap bagian dari karakter maskulin yang dimiliki laki-laki. Rokok hanya boleh dikonsumsi oleh laki-laki sebagai simbol kejantanan, kesuksesan, atau kekuasaan. Sebaliknya, perempuan yang mengonsumsi rokok akan diberi label perempuan jalang, sundal, atau nakal (Krisdinanto 2014). Dalam konteks Indonesia, misalnya, laki-laki merokok dianggap normal dan bagian dari tatanan sosial. Tetapi sebaliknya, praktik merokok di kalangan perempuan dipersepsi sebagai perilaku nakal dan tidak diberi tempat di tatanan sosial (Handayani 2012).

Di luar rokok, tato dan alkohol juga dilihat sebagai bagian dari maskulinitas laki-laki dan penggunaannya oleh perempuan akan dianggap sebagai praktik yang menyimpang. Makna tato, mengutip Sukendar et al. (2015), telah mengalami perubahan mengikuti perubahan zaman. Dahulu tato mempunyai fungsi atau nilai sosio-kutural tertentu, tetapi saat ini telah bergeser menjadi fungsi atau nilai yang lebih personal. Saat ini, fungsi atau nilai sosial tato menjadi sangat beragam, mulai dari bagian dari seni, ekspresi maskulinitas, kriminalitas, resistensi (perlawanan) hingga ekspresi.

Pada titik ini munculnya fenomena Danilla Riyadi, seorang penyanyi yang berangkat dari jalur indie, dan dikenal tidak hanya dari album atau lagu-lagunya yang menjadi hit. Danilla ini juga menjadi unik karena ekspresi-ekspresinya di media sosial, terutama di Instagram dan Youtube, yang terlihat "berkonfrontasi" secara diametral dengan apa disebut gender taboo. Secara terbuka, bahkan dengan bahasa lantang dan gestur yang provokatif, Danilla mengekspresikan sikap serta pandangannya terhadap hal-hal yang dianggap tabu bagi perempuan seperti rokok, tato, atau alkohol. Danilla adalah perempuan public figure yang memiliki keberanian mengekspresikan diri secara terbuka memamerkan tato di tubuhnya. Danilla juga sering tampak membagi foto dan video yang memperlihatkan dirinya merokok, minum alkohol, atau mengucapkan kata-kata "jorok" (terkait alat kelamin pria) pada akun Instagram dan akun Youtube miliknya maupun public figure lain.

Salah satu momen yang paling memicu kontroversi adalah ketika Danilla muncul dalam akun salah satu Youtuber, Gofar Hilman. Dalam podcast yang di-upload pada 30 Desember 2018 tersebut, ekspresi dan gestur Danilla tampak secara frontal menabrak tabu-tabu gender. Dalam acara yang diberi judul "1 Jam Bersama Danilla \#Ngobam” itu, Danilla tampak 
mengenakan kaos hitam berlengan pendek, yang menampakkan lengannya yang bertato. Di sela-sela wawancara, Danilla bersama juga berkali-kali menyalakan dan mengisap rokok, dan disusul meminum alkohol. Semua dilakukannya persis di depan kamera. Materi pembicaraan tidak hanya berkisar karir bermusiknya, tetapi juga menyangkut persoalan-persoalan yang masuk ke dalam ranah gender taboo yaitu rokok, tato, alkohol, dan seks. Di tengah wawancara, secara vulgar Danilla bahkan terlihat memenuhi tantangan Gofar Hilman untuk meneriakkan kata yang merujuk alat kelamin laki-laki.

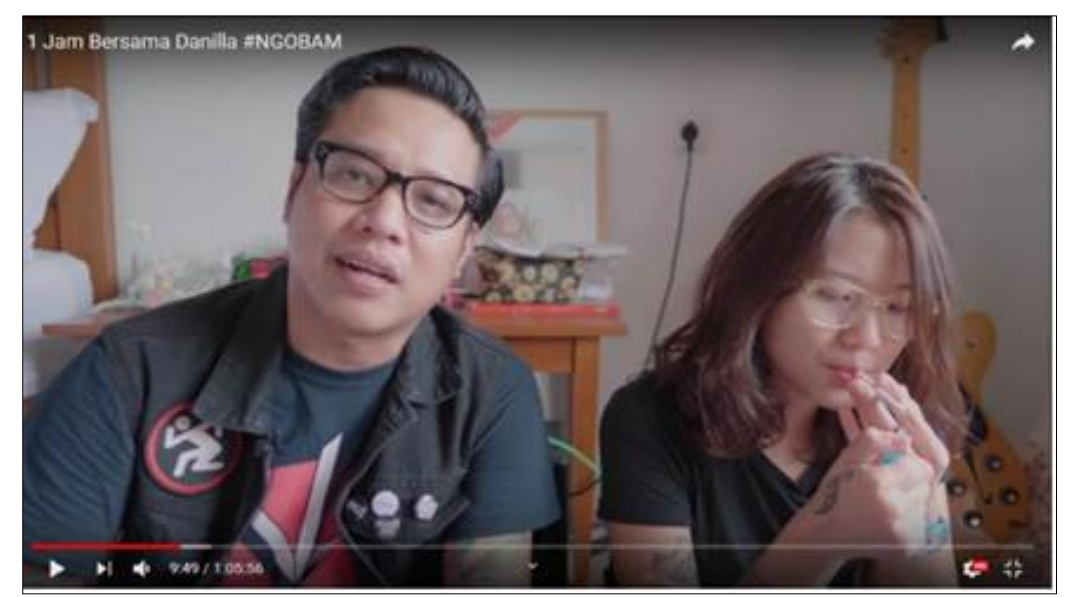

Gambar 1: Acara “1 Jam Bersama Danilla \#Ngobam” dari Hilman (2018)

Konten serupa juga kerap muncul di akun Instagram Danilla, yaitu @ danillariyadi. Gaya hidupnya yang dekat dengan praktik yang dianggap masuk ke dalam ranah gender taboo muncul secara rutin dan menjadi hal yang seolah normal dalam kesehariannya, baik berupa konten yang masuk ke dalam fitur Feeds, IG Story, maupun IG TV.

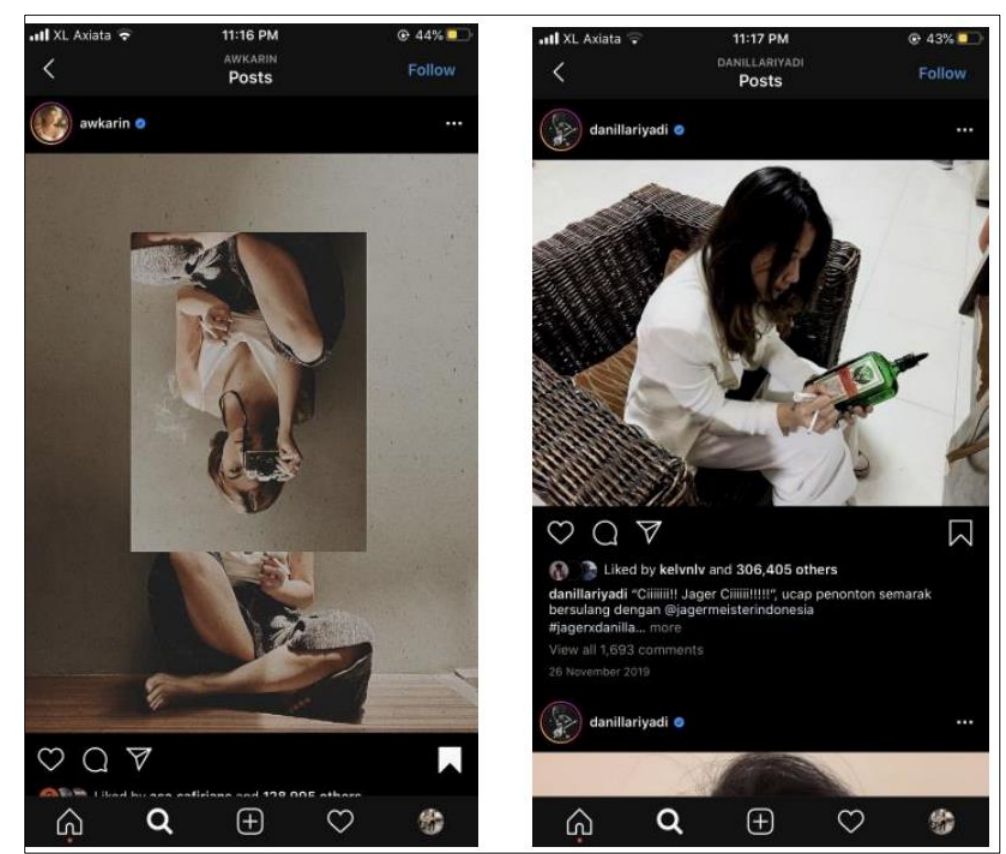

Gambar 2: Danilla memegang rokok dan botol alkohol, dari @danillariyadi (2019) 
Praktik membagi kehidupan pribadi kepada publik seperti yang dilakukan Danilla ini sebetulnya juga dilakukan banyak selebgram atau Youtuber laki-laki di media sosial, seperti Gofar Hilman sendiri, Denny Sumargo, Komika Uus, Onadio, dan sebagainya. Konten-konten mereka kerap diwarnai munculnya rokok, alkohol, tato, atau ucapan-ucapan sarkas bahkan kasar. Namun dalam konteks gender, unggahan mereka dianggap biasa dan tidak memicu kontroversi karena audiens (netizen) melihat mereka sebagai laki-laki yang secara norma atau nilai sosial dianggap pantas mempunyai tato atau merokok. Merokok dan minum alkohol di ruang publik, merujuk Sukendar et al. (2015) mempunyai dan menunjukkan tato dianggap sebagai hal biasa dan dipersepsi sebagai ekspresi maskulinitas yang normal. Bahkan aktivitas tersebut terlihat sengaja dilakukan untuk melakukan pencitraan di media sosial, sebagaimana disebutkan oleh Pattipeilohy (2015), bahwa media massa berfungsi sebagai perpanjangan indra manusia. Citra public figure akan sangat ditentukan oleh apa yang dilihat dan dinilai oleh audiens (netizen) melalui konten di media massa atau media sosial.

Sedangkan kolom komentar akun Instagram Danilla Riyadi dipenuhi pro-kontra, apalagi mengingat saat ini akun @ danillariyadi ini di-follow sekitar 1,4 juta akun. Kolom komentar di akunnya menjadi medium interaksi antar akun untuk berdiskusi, berdebat, atau bahkan saling mengolok terkait gender taboo. Danilla sendiri, di dalam akunnya sering mengekspresikan pendapatnya bahwa perempuan juga punya hak terkait soal rokok, tato, dan alkohol, meskipun masyarakat diakui akan memandang perempuan tersebut secara negatif.

Pada titik ini, media sosial memang sudah menjadi medium yang memfasilitasi beragam ekspresi individu, termasuk terkait gender taboo, seperti dilakukan Danilla Riyadi maupun selebgram atau Youtuber lainnya. Menurut Setiadi (2014), media sosial merupakan medium di internet yang memberi peluang penggunanya untuk berinteraksi atau merepresentasikan dirinya dan secara virtual membentuk ikatan sosial. Sedangkan Nugraheni \& Anastasia (2017) menulis, media sosial memang merupakan media yang mempunyai fokus pada eksistensi pengguna dan memungkinkan mereka untuk membagikan kegiatan sehari-hari maupun berkolaborasi melalui konten. Karena itu, media sosial diposisikan sebagai medium yang menciptakan ikatan sosial serta menguatkan hubungan antar penggunanya (Nasrullah 2018).

Media sosial kini telah menjadi medium di mana public figure membagi kehidupan sehari-harinya. Fenomena inilah yang mendorong media sosial melebur ruang privat dengan ruang publik (Ayun 2015). Privasi merupakan perlindungan dari ekspresi identitas diri atau kepribadian seseorang melalui pembicaraan dan kegiatan. Penggunaan Instagram dan Youtube oleh public figure, disadari atau tidak, memengaruhi pengikutnya. Keduanya dianggap media yang terbuka bagi siapapun untuk mengekspresikan diri di ruang publik, yang kemudian dapat mempengaruhi persepsi masyarakat (Krisnawati 2017).

Keberanian Danilla menggunakan media sosial sebagai medium ekspresi diri melalui rokok, tato, dan alkohol ini bisa dilihat sebagai upaya "konfrontasi" dirinya melawan gender taboo. Merujuk Misel (2017), pada dasarnya tidak satupun perempuan ingin disebut jalang atau dalam bahasa Inggris sering dinyatakan sebagai "bitch". Tetapi munculnya gelombang ke-3 dalam gerakan feminis di dunia Barat telah menggeser makna kata "bitch" atau jalang. Menjadi "bitch" atau perempuan jalang saat ini lebih dilihat sebagai simbol keberanian, kebebasan dari diskriminasi gender.

Sampai di sini, mencermati respon audiens terhadap konten-konten media sosial dari Danilla Riyadi menjadi menarik, karena isi konten-konten tersebut juga terkait erat dengan praktik sosial keseharian dari audiens. Yang dimaksud sebagai audiens adalah followers yang melihat atau secara aktif mengomentari konten terkait Danilla. Karena pesan-pesan yang terkandung dalam ekspresi Danilla Riyadi seringkali bersifat "melawan" rumusan baku tentang gender taboo, maka respon atau pemaknaan audiens/ followers terhadap pesan itu juga 
menjadi menarik. Apalagi audiens juga hidup dalam tatanan sosial yang sama, dengan problematika keseharian yang serupa pula.

Dalam kajian audiens, perbedaan individu dalam memaknai pesan ini sering dipahami melalui proses encoding dan decoding, Merujuk Hall (2011), di antara produser (encoder) dan audiens (decoder) seringkali muncul perbedaan dalam memaknai pesan, karena adanya perbedaan posisi atau relasi. Perbedaan dalam memberi makna tersebut berakar pada apa yang disebut kode (frameworks of knowledge, relations of production, technical infrastructure) yang dipahami oleh masing-masing ketika menyusun (encoding) dan menerima (decoding) pesan melalui media.

Merujuk Alasuutari (1999), terdapat tiga posisi dalam pemaknaan audiens terhadap pesan teks media, yaitu dominant/ hegemonic reading, oppositional reading, dan negotiated reading. Dominant reading, menurut Pujileksono (2016) terjadi bila audiens menerima atau menyepakati makna yang disusun oleh pembuat program atau penyusun teks media, atau jika audiens memosisikan dirinya sejalan dengan kode-kode (yang bermuatan asumsi, keyakinan. nilai, atau sikap) yang ada dalam teks media. Sedangkan negotiated reading merupakan posisi di mana audiens menyepakati atau menerima makna yang disajikan oleh penyusun teks media, tetapi berupaya melakukan modifikasi agar juga mencerminkan minat atau posisi pribadinya. Sementara oppositional reading mencerminkan posisi penolakan audiens terhadap kode-kode di dalam teks media, bahkan kemudian menentukan frame alternatif sendiri dalam memaknai isi teks media tersebut.

Seseorang bisa memiliki posisi berbeda sebagai implikasi dari perbedaan field of experience (FOE) dan frame of reference (FOR). FOE dan FOR ikut memengaruhi seseorang dalam memaknai gender taboo. Dalam kasus Danilla, umumnya cara berpikir masyarakat telah dibentuk oleh frame of reference yang melihat perempuan memang tidak pantas untuk merokok, memiliki tato, dan minum alkohol. Hal-hal ini akan ikut menentukan cara audiens memaknai ekspresi penilakan terhadap gender taboo oleh Danilla di media sosial.

Secara tidak langsung, mengutip Weber (dalam Sulaiman 2016) cara seseorang memberi makna terhadap tindakan orang lain juga dipengaruhi oleh makna "tersembunyi atau melekat" pada sebuah objek. Sedangkan pemaknaan terhadap sebuah objek ikut ditentukan oleh lingkungan sekitar, budaya, dan persepsi individu. Karena itu, budaya memiliki ikatan kuat dengan persepsi atau disebut sebagai culture bound (Mulyana 2009). Berdasar hal tersebut, penelitian ini menggunakan analisis resepsi sebagaimana dikembangkan Stuart Hall. Melalui riset ini bisa diketahui bagaimana audiens menerima pesan atau ekspresi "perlawanan" terhadap gender taboo yang dilakukan Danilla Riyadi di media sosial.

\section{METODOLOGI PENELITIAN}

Dalam penelitian ini, peneliti menggunakan pendekatan kualitatif, dengan tipe deskriptif, dan metode analisis resepsi (reception analysis). Menurut Jensen (dalam Pujileksono 2016), analisis resepsi mengkaji proses-proses aktual melalui makna wacana media yang disesuaikan dengan wacana dan praktik budaya audiensnya. Subjek dalam penelitian ini adalah perempuan yang menjadi follower akun @danillariyadi dengan beberapa kriteria. Kriteria utama adalah berjenis kelamin perempuan, mengingat objek yang dikaji dalam penelitian ini adalah gender taboo yang meletakkan perempuan pada posisi tersubordinasi. Di sini akan bisa dilihat apakah konten "perlawanan” Danilla Riyadi terhadap gender taboo bisa menghasilkan kesadaran yang sama di kalangan follower-nya yang menjadi subjek penelitian.

Subjek atau informan penelitian dipilih dengan beberapa kriteria. Pertama, audiens atau penonton berjenis kelamin perempuan karena fokus peneliti terletak pada gender taboo yang dilakukan Danilla Riyadi sebagai perempuan perokok. Peneliti juga memfokuskan perempuan 
sebagai subjek penelitian karena perempuan diposisikan sebagai warga kelas dua (subordinat). Kedua, subyek yang berada pada fase dewasa, yaitu berumur 21-40 tahun. Secara psikologis, pada umur tersebut informan memiliki tingkat kematangan berpikir dan juga memiliki cukup banyak pengalaman. Ketiga, tingkat pendidikan SMA, sedang berkuliah, lulusan strata-1 (S1) atau sudah bekerja. Hal ini ditentukan karena peneliti memerlukan pemaknaan dengan penjelasan yang bisa disampaikan dengan baik. Berikut ini adalah tabel subjek penelitian.

Tabel 1: Subjek Penelitian

\begin{tabular}{lcll}
\hline \multicolumn{1}{c}{ NAMA } & USIA & \multicolumn{1}{c}{ PEKERJAAN } \\
\hline Berna Detha Steffani Wardana (Fani) & 21 tahun & $\begin{array}{l}\text { Mahasiswa, staf kantor developer, } \\
\text { wirausaha }\end{array}$ \\
\hline Aveline Catherine & 22 tahun & Karyawan \\
\hline Yuliana Kurniawan & 32 tahun & Bisnis katering \\
\hline Sarah Yoshina Siautta & 22 tahun & Baru lulus S1 \\
\hline Amadea Nathania & 22 tahun & Wirausaha, lulusan S1 \\
\hline Citha Kusuma Nindita & 25 tahun & Wirausaha \\
\hline
\end{tabular}

Sumber: data olahan peneliti, 2020

Untuk mengoleksi data, peneliti menggunakan teknik wawancara mendalam (in-depth interview). Peneliti menunjukkan sejumlah konten Youtube dan Instagram yang sesuai tema penelitian, dan menggali respon pemaknaan subjek penelitian melalui wawancara mendalam. Cara ini biasa digunakan untuk menggali data secara mendalam. Wawancara mendalam dilakukan secara intensif dan berulang-ulang. Peneliti tidak memiliki kontrol terhadap respon subjek penelitian, dan mereka bisa bebas menjawab pertanyaan (Kriyantono, 2014). Berdasarkan data yang diperoleh melalui in-depth interview dalam bentuk percakapan (verbal) dan nonverbal dengan narasumber atau informan, lalu disajikan data dalam bentuk transkrip. Berdasarkan hasil transkrip pemaknaan informan ini, kemudian transkrip akan dianalisis dan dikategorikan oleh peneliti menggunakan tiga kategori hipotesis yang diungkapkan oleh Morley (dalam Adi 2012), yaitu dominant, negotiated, dan oppositional reading. Penelitian ini memosisikan informan ke dalam tiga kelompok kode yaitu dominant, negotiated, dan oppositional. Untuk menguraikan serta membahas hasilnya, peneliti membaginya ke dalam dua bagian dengan sub-tema yang berbeda.

\section{HASIL DAN PEMBAHASAN}

\section{Mendefinisikan Ulang 'Bitch' Melalui Rokok, Tato, dan Alkohol}

Pada bagian ini, peneliti menunjukkan sejumlah konten Instagram dan Youtube saat Danilla Riyadi sedang merokok, minum alkohol dan menunjukkan tato di lengannya. Tahun 2016 merupakan tahun pertama Danilla membagikan video dirinya bermain gitar sambil memegang sebatang rokok. Video tersebut menjadi konten pertamanya yang muncul di depan publik dengan rokok di jemarinya. Hal ini memancing beragam respon dalam kolom komentar Instagram Danilla. Setelah itu, tampilan-tampilan Danilla di akun Instagramnya sering diwarnai rokok, alkohol, dan tato, seperti gambar berikut. 


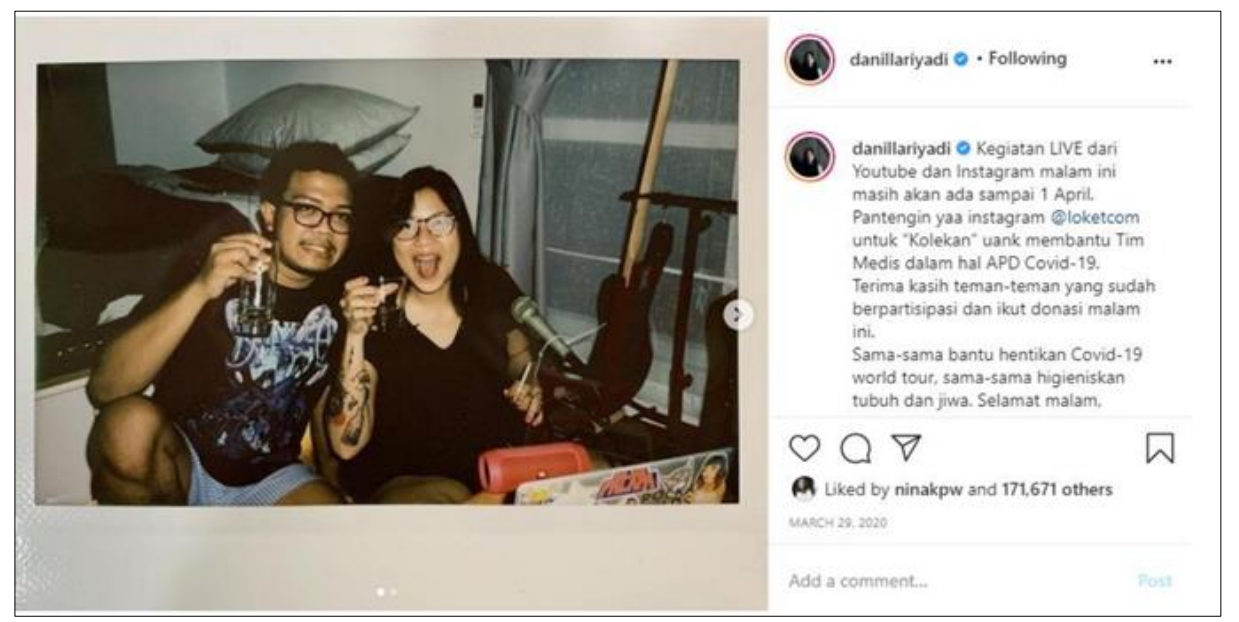

Gambar 3: Danilla memegang rokok dan gelas alkohol, dari @ danillariyadi (2020)

Saat tampil dalam konten Youtube "Baru Kenal" milik komedian Uus yang di-upload pada 21 Februari 2020), Danilla menceritakan kekecewaannya pada pandangan masyarakat mengenai perempuan merokok, bertato, dan minum alkohol. Menurut Danilla, tidak ada yang salah dari perilaku perempuan merokok, bertato, dan minum alkohol selama tidak merugikan orang lain. Namun masyarakat telanjur mencampuri urusan pilihan seorang perempuan untuk merokok, bertato, dan minum alkohol dengan tatanan sosial. Masyarakat seringkali menganggap perempuan merokok merupakan perilaku yang tidak biasa.

"Kadang ada komen yang ngomong, suara Danilla bagus sayangnya kok ngerokok. Terus gue kayak pengen tanya, lu suka kerko band atau siapalah. Mereka ngerokok juga, so jangan mentang-mentang cewek terus dibatasin. Kan gue yang nanggung ruginya" (Danilla Riyadi, 21/02/2020).

Saat ditunjukkan kepada subjek penelitian, respon mereka beragam. Fani, Yuliana, dan Sarah cenderung melihat apa yang dilakukan dan dikatakan Danilla Riyadi sebagai hal biasa dan normal, bahkan perlu dilakukan untuk menunjukkan posisi perempuan.

"Kalau aku gini sih. Sekarang memang Danilla itu public figure perempuan tapi kan ada contoh seperti Ibu Susi mantan menteri kelautan, beliau juga ngerokok, punya tato, dan minum. Mereka ini kan sama-sama perempuan tapi kan nggak ada yang salah kalau cewek ngerokok, sama aja kok seperti laki-laki yang merokok. Kenapa harus dibedakan, selama tidak mempengaruhi kinerja atau karya seseorang itu ya gapapa. Toh kita juga gak rugi. Mending melihat karya dan hasil kerja dari pada hanya melihat perilakunya saja. Kalau dengan menjadi diri sendiri mereka bisa lebih baik kenapa tidak gitu”" (Fani, 26/11/2020).

"Kalau menurutku sih tidak ada yang salah dari foto ini. Karena perempuan merokok itu berarti dia bebas menentukan pilihannya sendiri kan, sedangkan lakilaki selama ini selalu bebas untuk menentukan apa yang mereka inginkan. Padahal sebenarnya kan sama aja dengan perempuan. Perempuan dan laki-laki merokok itu kan pilihan. Mau sampai kapan kita atau orang lain melihat bahwa perempuan tidak berhak memilih apa yang dia inginkan dan mau sampai kapan juga perempuan harus memiliki citra seperti apa yang diinginkan oleh masyarakat" (Sarah, 28/11/2020). 
Jawaban Fani dan Sarah ini menggambarkan apa yang disebut Handayani (2012) bahwa perempuan merokok dianggap tidak punya tempat dalam tatanan sosial. Keduanya terlihat menuntut perlakuan atau persepsi yang adil terhadap perempuan yang merokok, yang selama ini secara sosial selalu dianggap buruk. Sebaliknya, laki-laki merokok dipandang normal dan bagian dari tatanan sosial. Namun apa yang dikatakan Fani dan Sarah mencerminkan penolakan terhadap tatanan sosial seperti itu. Apa yang dilakukan Danilla tidak dipahami sebagai lambang buruknya perilaku perempuan, melainkan simbol keberanian dan perlawanan terhadap sistem sosial yang menindas perempuan. Inilah kerancuan yang selalu muncul dalam perbincangan di seputar wacana keperempuanan yang kebanyakan berkutat pada asumsi pemilahan dikotomis terkait isu maskunilitas-feminitas atau wilayah domestik-publik yang merugikan perempuan (Wibowo 2011).

Mengutip Levit (1998), gender merupakan sesuatu yang dikonstruksi yang membuat orang percaya bahwa perempuan dan laki-laki memang berbeda dalam hal ketertarikan, keinginan, dan kemampuan. Hal tersebut menunjukkan bagaimana perempuan dan laki-laki dipisahkan oleh konstruksi gender, sedangkan gender sendiri terbentuk karena adanya budaya yang mengkonstruksi dan membagi perempuan dan laki-laki. Sehingga akhirnya gender memisahkan perempuan dengan haknya untuk memilih apa yang dia inginkan. Keduanya merasa perempuan merokok, bertato, dan minum alkohol seringkali menjadi perdebatan sosial. Bahkan Sarah merasa perempuan tidak perlu menjaga citranya hanya untuk menjadi seperti apa yang diinginkan masyarakat. Pendapat keduanya menggambarkan bagaimana masyarakat menilai perempuan merokok, bertato, dan minum alkohol dibandingkan dengan laki-laki yang merokok, bertato, dan minum alkohol.

Posisi pemaknaan Fani dan Sarah ini bisa jadi terkait dengan pengalamannya sendiri (field of experience). Di lingkungan kerjanya, keduanya mengaku sering menemukan perempuan merokok, bertato, dan minum alkohol. Meskipun Fani bukan perokok aktif, tetapi dirinya memiliki pasangan yang merokok, bertato, dan minum alkohol. Fani juga mengaku di kala tertentu dirinya masih mengisap vapor atau rokok elektronik. Meskipun keluarga Fani sangat menentang perempuan yang merokok, namun keluarganya mulai bisa menerima budaya minum alkohol bersama dan menerima pasangan Fani yang merokok, bertato, dan minum alkohol. Sedangkan Sarah hingga saat ini masih aktif merokok, bahkan baru-baru ini membuat dua tato pada tangan kanan dan kirinya. Hal ini dilakukan tanpa sepengetahuan keluarganya yang sangat tertutup dengan rokok, tato, dan alkohol bagi perempuan. Namun Sarah memutuskan tetap merokok dan memberanikan diri membuat dua tato pada tangannya karena Sarah merasa ingin menjadi dirinya sendiri. Sarah juga mencoba mengkomunikasikan kepada orangtuanya bahwa tidak selamanya perempuan merokok bisa diidentikkan dengan perempuan jalang atau nakal.

Selain itu, lingkungan pekerjaan Sarah juga mendukung opini dan pandangan Sarah terhadap perilaku merokok, bertato dan minum alkohol di kalangan perempuan. Sarah berada dalam lingkungan pekerjaan publik sebagai barista pada sebuah kafe. Hal ini mencerminkan yang dinyatakan oleh Walby (1991) bahwa patriarki dibagi dalam dua bentuk, yaitu patriarki publik (public patriarchy) serta patriarki domestik (private patriarchy). Patriarki domestik menggarisbawahi kerja dalam rumah tangga sebagai bentuk stereotipe yang ditempelkan kepada perempuan, sementara laki-laki bisa memiliki ruang gerak di dalam ruang publik. Pada titik ini, secara implisit ketiga subjek penelitian ini mengafirmasi penolakan Danilla terhadap gender taboo, dan ikut berusaha merumuskan ulang posisi perempuan dalam tatanan patriarki dengan cara memosisikan diri menjadi "bitch".

Berseberangan dengan mereka, subjek penelitian Dea dan Citha memosisikan diri menolak apa yang dilakukan Danilla melalui media sosial. Selain permasalahan kesehatan, mereka juga mempermasalahan seorang perempuan merokok, bertato, dan minum alkohol. 


\begin{abstract}
"Sebenarnya aku juga tidak setuju laki-laki merokok apalagi perempuan merokok. Tapi kalau lihat laki-laki merokok aku seperti ya sudahlah karena banyak juga lakilaki merokok dan sudah dari dulu kan. Tapi kalau perempuan, aku ga setuju banget bahkan pertama lihat aja aku langsung merasa aneh dan ya itu tadi terlihat nakal. Mungkin karena apa ya ajaranku dari kecil sudah diajarkan perempuan itu seperti apa, jadi ketika melihat perempuan merokok, bertato, dan minum alkohol itu aneh. Tidak terbiasa aja" (Dea, 30/11/2020).

"Menurutku sih kalau kepintaran orang ga bisa dilihat dari rokok atau tidaknya. Tapi kalau dia merokok sepertinya kurang pantas apalagi ditunjukan untuk media sosial. Seolah seperti mempromosikan dan mempengaruhi orang lain gitu. Perempuan lagi kan jadi aneh banget terlihat nakal gitu. Laki-lakipun menurutku ya bermasalah kalau mereka merokok, karena untuk kesehatan itu tidak baik. Kalau laki-laki aja ga baik apalagi perempuan merokok. Aneh dan nakal banget sih kesannya menurutku” (Citha, 30/11/2020).
\end{abstract}

Jawaban Dea dan Citha ini meneguhkan yang ditulis (Krisdinanto, 2014) bahwa dalam kasus rokok, perempuan perokok diberi label sebagai perempuan sundal, pelacur, berupaya menarik lawan jenis, dan sebagainya, sementara laki-laki yang merokok dipersepsi sebagai sosok yang sukses, berwibawa, dan memiliki kekuasaan. Keduanya merasa aneh dan langsung menilai Danilla merupakan sosok perempuan nakal ketika melihat konten Instagram Danilla. Bahkan ketika wawancara berlangsung terlihat cukup jelas kekecewaan Dea saat melihat foto Instagram Danilla. Meskipun pada saat wawancara Dea juga mengatakan tidak ingin perempuan ditindas dan selalu dianggap sebagai nomor dua namun merokok, bertato, dan minum alkohol juga bukan cara untuk melakukan pembebasan perempuan dari konstruksi gender. Jawaban Dea dan Citha ini dipengaruhi latar belakang mereka, terutama keluarga yang sejak kecil mengajarkan bahwa perempuan yang merokok itu nakal. Dalam keluarga Dea dan Citha tidak ada yang merokok, bertato, dan minum alkohol.

Subjek penelitian yang terlihat memosisikan di tengah adalah Catherine. Dia merasa tidak ada masalah dengan konten Danilla. Namun di sisi lain Catherine juga tidak sepenuhnya menyetujui konsep merokok, bertato, dan minum alkohol karena menurutnya ada alasan kesehatan yang penting untuk dijaga.

\begin{abstract}
"Aku setuju aja sih karena itu hidupnya mereka. Cuma kembali ke pilihanku sendiri, aku ga mau ditato atau merokok. Karena menjaga diriku sendiri juga supaya ga dianggap atau dipandang aneh sama orang. Kan biasanya banyak orang yang memandang perempuan merokok itu aneh, nakal dan ga baik. Terus kalo menurut aku ngerokok itu aku ga baik juga sih buat kesehatanku. Jadi kalau aku sendiri ga mau sih, tapi kalau melihat orang lain ya ga papa karena pilihan orang" (Catherine, 21/11/2020).
\end{abstract}

Kalimat yang diucapkan Catherine mengenai "karena menjaga diriku sendiri juga supaya ga dianggap atau dipandang aneh sama orang" ini menunjukkan dirinya tidak siap untuk dipandang sebagai perempuan jalang. Dirinya lebih memilih untuk tidak merokok, bertato, dan minum alkohol agar tidak memiliki citra buruk di masyarakat. Dia memiliki latar belakang yang hampir sama dengan Yuliana, di mana dirinya memiliki seorang Ayah yang sudah merokok sejak Catherine kecil. Namun hal ini tetap tidak mendorong Catherine untuk merokok. Bahkan Catherine juga memiliki kakak laki-laki dan kakak perempuan, dan semuanya tidak merokok atua bertato. Melihat ayahnya merokok tidak menjadikan Catherine untuk menjadi seorang perokok, karena menurutnya merokok bukan hal yang baik untuk 
kesehatan. Saat proses wawancara Catherine menjelaskan bahwa dirinya menghargai keputusan perempuan lain yang memilih untuk merokok, namun bukan berarti mengikuti gaya hidup merokok.

Schramm (dalam Effendy, 2003) menyatakan, hal penting dalam proses encoding dan decoding juga didukung apabila komunikator dapat menyusun (encoding) dan komunikan dapat menerima (decoding) makna pesan berdasar pengalamannya. Komunikasi dapat berhasil atau efektif bila pesan komunikator selaras dengan kerangka acuan (frame of reference) yang merupakan perpaduan pengertian dan pengalaman (collection of experiences and meanings) yang pernah diperoleh masing-masing individu. Pengalaman (field of experience) dilihat sebagai hal penting dalam berkomunikasi. Persamaan bidang pengalaman antara komunikator dan komunikan membuat pesan yang disampaikan menjadi kian efektif.

Dalam pengelompokan posisi jawaban, Fani, Sarah, dan Yuliana bisa disebut berada pada posisi dominant. Hal ini berarti menunjukkan ketiganya juga memaknai konten Danilla sama dengan yang dikehendaki oleh Danilla sebagai pengirim pesan. Ketiganya merasa tidak ada yang salah dari konten Danilla, bahkan mereka senang karena Danilla bisa mengekspresikan dirinya terhadap hal yang dipilih oleh Danilla. Sedangkan Catherine memiliki jawaban yang berbeda dibanding lainnya yang bisa dikelompokkan ke dalam posisi negotiated. Di satu sisi, Catherine memang merasa tidak terganggu dengan konten Danilla yang mengekspresikan sikapnya dengan terbuka terkait rokok, tato, dan alkohol. Namun di sisi lain, Catherine memiliki keraguan karena dirinya sebenarnya merasa perempuan merokok itu aneh dan dibalik itu menurutnya merokok tidak baik bagi kesehatan.

Sementara Dea dan Citha bisa dikelompokkan ke dalam posisi oppositional. Keduanya menolak atau tidak selaras dengan kode-kode pesan yang melekat pada konten Danilla. Terlebih hal ini dilakukan oleh Danilla melalui media sosial yang dapat dilihat oleh berbagai kalangan usia. Selain khawatir akan pengaruh perilaku Danilla terhadap anak-anak di bawah umur, mereka juga merasa terganggu karena Danilla sebagai perempuan yang merokok, bertato, dan minum alkohol. Posisi penerimaan subjek penelitian terkait ini tergambar dalam tabel berikut.

Tabel 2: Posisi Penerimaan Terkait Rokok, Tato, dan Alkohol

\begin{tabular}{llll}
\hline \multicolumn{1}{c}{ Temuan data } & \multicolumn{3}{c}{ Posisi } \\
\cline { 2 - 4 } & Dominant & Negosiated & Oppositional \\
\hline Penerimaan terhadap & Fani & Catherine & Dea \\
konten gender taboo & Yuliana & & Citha \\
Danilla Riyadi & Sarah & & \\
\hline
\end{tabular}

Sumber: data olahan peneliti, 2020.

\section{Antara Ucapan Kasar dan Maskulinitas}

Salah satu pernyataan atau ekspresi paling “epik" dari Danilla Riyadi di media sosial adalah saat dirinya diundang oleh Youtuber Gofar Hilman untuk diwawancara di channelnya dan diunggah 30 Desember 2018. Konten ini ditonton sekitar 6,6 juta orang, dan seketika memicu kontroversi. Dalam acara yang diberi tajuk "1 Jam Bersama Danilla Riyadi \#Ngobam" itu, Danilla menenuhi tantangan Gofar Hilman, dan berteriak dengan suara keras di depan kamera: "Nih buat lu semua, $\mathrm{K}^{* * * * 1}$..." (sebutan untuk alat kelamin laki-laki).

Awalnya, Danilla menceritakan awal mula kalimat kasar yang dia ucapkan ini menjadi viral. Dirinya menceritakan bahwa hal ini terjadi karena ada rekan kerjanya bergurau dengan berteriak "Danilla Gendut". Ucapan rekannya ini terekam dalam video karena saat itu Danilla memang sedang mempromosikan sebuah acara melalui Instagramnya. Setelah mendengar ucapan tersebut, Danilla membalas dengan berteriak: "K****1...". Video ini ramai 
dibicarakan di media sosial, bahkan banyak netizen yang mengunggah ulang video ini. Setelah viral, Danilla sempat mengunggah foto hasil karyanya yang mendapatkan penghargaan pada salah satu majalah. Namun dalam foto ini dirinya terlihat sedikit "berisi" dibanding biasanya. Akhirnya netizen beramai-ramai mengkomentari fotonya dengan sebutan "Cici gendut". Ungkapan ini banyak diucapkan netizen ketika bertemu Danilla secara langsung seperti di konser atau acara lainnya. Setelah semakin banyak netizen yang memanggilnya dengan sebutan tersebut, Danilla mengaku geram karena merasa banyak yang sengaja menghina dirinya. Danilla mengungkapkan kekesalannya ini dalam wawancaranya dengan Gofar. Hingga akhirnya Danilla mengatakan dirinya merasa netizen yang sengaja memanggilanya "Cici gendut" itu seolah ingin dibalas dengan jawaban " $\mathrm{K}^{* * * * 1 " ~ s e p e r t i ~ D a n i l l a ~ m e m b a l a s ~}$ rekan kerjanya. Akhirnya Danilla berteriak sambil melihat kamera dan menyebutkan kata umpatan tersebut.

Ketika konten ini ditunjukkan kepada subjek penelitian, respon mereka juga menunjukkan keberagaman spektrum penerimaan. Sama halnya dengan rokok, tato, atau alkohol, gender taboo bisa pula dikaitkan dengan ucapan kata-kata kotor bagi perempuan. Dalam konteks tertentu, frase-frase yang bisa dikategorikan kasar atau bahkan kotor/ jorok dianggap normal diucapkan oleh laki-laki. Bahkan dalam konteks tertentu, kata-kata itu bisa dimaknai sebagai ekspresi kedekatan atau keakraban di antara laki-laki. Mengumpat juga dilihat tidak patut dilakukan perempuan karena dianggap tidak mencerminkan karakter feminin. Di dunia media sosial, cukup banyak content creator yang dikenal suka berbicara kasar seperti Gofar Hilman sendiri, Onad, Uus, atau Denny Sumargo. Namun tidak muncul kontroversi yang berarti mengingat mereka laki-laki. Subjek Yuliana dan Sarah yang dalam soal rokok, tato, dan alkohol berposisi dominant, bahkan terlihat kaget melihat umpatan Danilla ini, meskipun kemudian terlihat mencoba memahami konteks cerita Danilla.

\begin{abstract}
"Sedikit kaget ya karena kata-kata itu, sebenernya menurut gua itu gak papa sih cuma mungkin karena tempatnya aja. Jadi kesannya kasar banget nih Danilla. Padahal kalau menurut gua ya itu ga teralu heboh dan biasa aja sih, karena pasti semua orang pernah ngomong kasar tapi tidak semua masuk Youtube. Sedangkan Danilla lebih tersorot aja karena dia public figure" (Yuliana, 24/11/2020).
\end{abstract}

"Menurutku sih tidak salah ya. Aku juga gak merasa terganggu dengan ucapan Danilla ini. Aku berkaca sama diriku sendiri juga yang sering ngomong kasar. Dan tidak menutup kemungkinan orang lain juga pasti pernah berbicara kasar, bedanya Danilla ini seorang public figure yang disorot. Jadi pasti langsung heboh gitu. Menurutku juga gak ada yang salah dengan Danilla ngomong di media sosial seperti itu, toh seperti Uus, Gofar, dan Onad itu juga sering banget ngomong kasar di Youtube bahkan Instagram. Jadi ya gak ada masalah" (Sarah, 28/11/2020).

Namun Yuliana dan Sarah mengakui, keduanya juga sering berbicara kasar seperti Danilla, sehingga menurut keduanya kata-kata kasar Danilla di Youtube ini merupakan ekspresi diri yang lumrah. Bahkan keduanya menyukai keberanian Danilla untuk berbicara apa adanya dalam media sosial. Peneliti juga bertanya bagaimana jika perkataan kasar Danilla di media sosial ini dapat memengaruhi orang lain, bahkan anak-anak di bawah umur. Keduanya menjawab bahwa yang seharusnya dapat memilah konten yang ingin dilihatnya adalah netizen itu sendiri. Sarah juga menambahkan ada kewajiban orangtua untuk mengawasi anak-anak di bawah umur dalam penggunaan gadget. Berbeda dengan Yuliana dan Sarah, keempat subjek penelitian lainnya berada pada posisi sebaliknya. Mereka merasa tidak nyaman dengan konten Danilla yang mengandung kata-kata kasar. Fani, Catherine, Dea, dan 
Citha sama-sama merasa konten ini mengganggu. Bahkan keempat subjek penelitian ini mengutarakan berbagai pendapat dan kekecewaan mereka terhadap Danilla.

\begin{abstract}
"Aku kurang setuju sih kalau untuk hal ini. Dengan Danilla yang berkata-kata kasar ini karena menurut aku ini bisa merugikan orang lain. Seperti misalnya yang aku bilang tadi tentang merokok, tato, dan alkohol, itu kan pilihannya Danilla sendiri dan kita tidak rugi apa-apa. Tapi kalau berbicara kasar apalagi sekotor ini melalui media sosial ya takutnya dilihat orang lain lalu diikuti banyak orang. Mungkin kalau dia melakukan di lingkungannya atau di tempat nongkrongnya gitu ga papa karena mereka saling mengenal gitu. Mungkin karena aku juga masih ketat dengan budaya Indonesia mengenai tata krama dan kesopanan yang diajarkan di keluargaku untuk hal seperti ini" (Fani, 26/11/2020).

"Aku kurang setuju sih dengan omongan kasar Danilla ini. Karena dia juga melakukan ini di ruang publik. Mungkin selebihnya kalau Danilla mau berbicara seperti itu hanya dengan temannya atau di lingkungannya Danilla sih ga papa ya. Karena kalau di Indonesia sini kan jarang ya ada public figure yang seperti itu, jadi di Indonesia dianggap tabu gitu. Dan takutnya hal ini mempengaruhi orang lain dengan jadi ikut ngomong kasar atau malah bisa menyakiti orang lain gitu" (Catherine, 24/11/2020).
\end{abstract}

Mengutip Allan and Burridge (2006), tabu adalah larangan terhadap perilaku yang bisa memengaruhi kehidupan sehari-hari. Tabu dapat disebabkan oleh kendala sosial yang dirasakan individu dalam masyarakat dan apabila ini dilanggar dapat menyebabkan ketidaknyamanan dan bahaya pada individu maupun kelompok. Pengertian ini menggambarkan apa yang disampaikan oleh Fani dan Catherine, di mana keduanya merasa kata kasar yang diucapkan Danilla bisa dikategorikan sebagai tabu terutama bagi perempuan. Ucapan kasar dianggap lebih milik laki-laki, karena bisa dikoneksikan dengan maskulinitas, ekspresi kedekatan atau persahabatan antar laki-laki. Dea dan Citha menangkap konten itu dengan penerimaan senada.

"Aku baru lihat sih video ini. Kok perempuan gitu sih. Ngomong kasar seperti itu sih sebenarnya tidak masalah ya kalau untuk kalangannya sendiri. Tapi inikan di media sosial ya, apalagi dia punya pengikut yang bisa dibilang banyak loh, 1,6 juta. Belum lagi di Youtube seperti ini. Jadi kurang pantas sih. Bukan contoh yang baik" (Dea, 30/11/2020).

"Menurut saya tidak sopan sekali ya. Maksudnya dia berbicara kasar, seperti dengan sengaja dan bangga dan aku tidak setuju sih. Apalagi ini di media sosial, takutnya mempengaruhi orang lain gitu lo" (Citha, 30/11/2020).

Saat wawancara, Dea menunjukan ekspresi kaget ketika mendengar perkataan kasar Danilla di Youtube. Setelah melihat video tersebut, Dea juga menunjukan ekspresi kecewa dan malu karena melihat Danilla sebagai public figure perempuan yang berbicara kasar di Youtube. Bahkan Dea tidak menyangka Danilla sebagai perempuan tetapi mengucapkan kata yang menyebutkan alat kelamin pria di media sosial. Dea sontak mengatakan "Kok perempuan gitu sih" sambil tertawa. Citha juga menunjukan ekspresi yang sama. Meskipun media sosial memang sudah sangat bebas untuk membuat sebuah konten, tetapi hal seperti ini dianggap tidak pantas. Secara ringkas, posisi subjek penelitian terkait konten ini bisa digambarkan sebagai berikut: 


\begin{tabular}{rlll}
\hline & \multicolumn{2}{c}{ Tabel 3: Posisi Penerimaan terhadap Ucapan Kasar } \\
\cline { 2 - 4 } Temuan data & \multicolumn{2}{c}{ Posisi } \\
\cline { 2 - 4 } & Dominant & Negosiated & Oppositional \\
\hline Penerimaan terhadap & Sarah & --- & Dea \\
konten gender taboo & Yuliana & Citha \\
Danilla Riyadi & & Catherine \\
& & Fani \\
\hline
\end{tabular}

Sumber: data olahan peneliti, 2020.

Mengacu temuan tersebut, subjek penelitian dapat dilihat telah menjadi penonton atau khalayak aktif dalam memaknai konten terkait gender taboo di Instagram dan Youtube Danilla. Seperti ditulis Nurudin (2017), masing-masing audiens memang mempunyai perbedaan dalam berpakaian, berpikir, merespon pesan berdasar pengalaman serta orientasi hidupnya. Gender taboo sendiri merupakan hal-hal atau perilaku yang dipisahkan berdasarkan gender seseorang. Seperti ditegaskan oleh Levit (1998), gender merupakan sesuatu yang dikonstruksi yang membuat orang percaya ada perbedaan di antara perempuan dan laki-laki dalam hal kemampuan, ketertarikan, atau keinginan. Budaya patriarki telah membatasi pandangan dan pilihan di antara perempuan dan laki-laki. Temuan penelitian ini memperlihatkan tidak ada audiens atau subjek penelitian yang memiliki jawaban relatif sama. Penerimaan mereka terhadap konten Danilla yang mengeskpresikan pesan perlawanan terhadap gender taboo ini berbeda-beda dengan berdasar field of experience atau frame of reference atau latar belakang budaya masing-masing subjek penelitian.

Dalam konteks kajian gender, beragamnya posisi penerimaan subjek penelitian tersebut bisa dilihat sebagai bagian dari dinamika upaya pendisiplinan (meminjam istilah Michel Foucault) terhadap perempuan oleh sebuah rezim patriarki. Patriarki menempatkan laki-laki sebagai penguasa tunggal dan sentral dari segala-galanya. Sistem ini membawa hak istimewa bagi laki-laki dan menjadikan perempuan sebagai objek yang berguna jika dapat dieksploitasi. Patriarki juga menempatkan laki-laki sebagai kontrol utama di masyarakat, sehingga dominasi terhadap perempuan tidak dapat terelakan (An Nur, Audyana \& Gurniawati, 2020). Pendisiplinan terhadap perempuan biasanya diantaranya dilakukan melalui mitos-mitos patriarki yang mengatur serta menetapkan standar norma tertentu dalam perilaku perempuan. Tujuan pendisiplinan tersebut adalah menciptakan normalisasi atau sesuatu yang dipertahankan sebagai sesuatu yang ideal (Adiyanto, 2021). Pada titik ini, gender taboo (yang dalam riset ini merujuk ke perilaku merokok, mengonsumsi alkohol, memiliki tato, atau berbicara kasar/ jorok) bisa dilihat sebagai bagian dari upaya pendisiplinan terhadap perempuan.

Lebarnya spektrum posisi penerimaan terhadap konten Danilla Riyadi yang mengonfrontasi gender taboo tersebut mencerminkan adanya dinamika di kalangan perempuan. Melalui posisi penerimaan yang menjadi hasil penelitian ini bisa dilihat munculnya penolakan atau resistensi terhadap upaya pendisiplinan tersebut yang tecermin pada posisi dominant reading. Dengan kata lain tabu-tabu gender yang selama ini berlaku dan dianggap benar sudah mulai dipertanyakan. Namun di sisi lain, karena sudah berakar sedemikian lama, sebagian lainnya masih terlihat mengafirmasi gender taboo tersebut melalui posisi oppotitional reading. Hasil-hasil ini mengisyaratkan adanya pergeseran di kalangan perempuan dalam memahami mitos-mitos patriarki yang sudah lama berkembang dan diyakini kebenarannya; yaitu mulai munculnya kesadaran kritis terhadap isu-isu gender yang selama ini membelenggu perempuan. 


\section{PENUTUP}

Berdasar hasil temuan data dan analisis, ada beberapa kesimpulan yang bisa ditarik. Pertama, secara teoritik riset ini semakin mengukuhkan tesis khalayak aktif, bahwa audiens memiliki kesadaran sendiri dalam memberi makna pada teks atau konten media sosial yang dikonsumsinya. Hal tersebut tecermin pada keragaman posisi yang diambil subjek penelitian dalam melihat konten media sosial Danilla Riyadi yang mencerminkan perlawanan diametral terhadap gender taboo, yang didemonstrasikan oleh Danilla melalui perilaku merokok, bertato, minum alkohol, dan ucapan kasar/ jorok. Konten yang berisi ekspresi perlawanan Danilla Riyadi terhadap gender taboo tersebut diresepsi dengan posisi yang beragam, yaitu dominant, negotiated, dan opposition, yang menunjukkan adanya otonomi kesadaran audiens dalam memaknai teks media. Kedua, temuan riset ini mencerminkan pula dinamika di dalam masyarakat terkait isu-isu gender. Di satu sisi, budaya patriarki masih terlihat dominan dalam struktur masyarakat dengan masih berlakunya aturan-aturan sosial yang mendiskriminasi perempuan. Namun di sisi lain, muncul kesadaran kritis dari perempuan yang menolak aturanaturan sosial tersebut, yang dalam riset ini difokuskan pada isu gender taboo. Label "perempuan nakal, jalang" atau yang dalam gerakan feminism di Barat sering disebut "bitch" secara implisit dipertanyakan oleh sebagian subjek penelitian, bahkan terkesan ingin didefinisikan ulang sebagai sesuatu yang menggambarkan kebebasan atau independensi perempuan. Dinamika tersebut tecermin dari spektrum penerimaan dari para subjek penelitian dalam meresepsi konten Danilla Riyadi, dan juga dari adanya pergeseran posisi dari sebagian subjek ketika meresepsi konten yang lain.

Dalam konteks kajian gender dan media (media sosial), penelitian ini bisa digunakan untuk menjelaskan fenomena kemunculan banyak content creator yang menggunakan isu-isu gender atau seks dalam konten-konten mereka. Riset ini juga bisa dikembangkan masuk ke dalam ranah metode lain, seperti fenomenologi, untuk bisa memahami pergulatan atau dinamika para content creator saat memproduksi konten-kontennya.

\section{REFERENSI}

@ danillariyadi. 2019. “Ciiiii Jager Ciiiiii.” Instagram. Retrieved (https://www.instagram.com/p/B5VMfyvne5A/).

@danillariyadi. 2020. "Kegiatan LIVE Dari Youtube Dan Instagram.” Instagram. Retrieved November 10, 2020 (https://www.instagram.com/p/B-SVOQFnwiX/).

Adiyanto, Wiwid. 2021. "Mitos Vagina Ideal Dalam Iklan Sabun Kewanitaan.” Jurnal Riset Komunikasi 4(1):160-78.

Alasuutari, Pertti. 1999. RETHINKING THE MEDIA AUDIENCE: The New Agenda. London: SAGE.

Allan, Keith, and Kate Burridge. 2006. Forbidden Words Taboo and the Censoring of Language. London: Bloomsbury Publishing.

An Nur, Fitrinanda, Ade Audyana, and Rahayu Gurniawati. 2020. "Ketidakadilan Gender Pada Acara Tv Sinema Indosiar: Telaah Perspektif Strukturasi Giddens." Jurnal Riset Komunikasi 3(1):96-107. doi: 10.24329/jurkom.v3i1.109.

Effendy, Onong Uchjan. 2003. Ilmu Komunikasi Teori Dan Praktek. Bandung: PT Remaja Rosdakarya.

Hall, Stuart. 2011. Budaya, Media, Bahasa. Yogyakarta: Jalasutra.

Handayani, Abmi. 2012. Perempuan Berbicara Kretek. Jakarta: Indonesia Berdikari.

Hilman, Gofar. 2018. "1 Jam Bersama Danilla \#NGOBAM.” Youtube. Retrieved November 10, 2020 (https://www.youtube.com/watch?v=daB15Q8IaaM\&t=2805s).

Krisdinanto, Nanang. 2014. "Menjual Rokok Melalui Kedustaan." in Komunikasi Budaya Pariwisata dan Religi, edited by Nurudin. Yogyakarta: Buku Litera. 
Krisnawati, Ester. 2017. "Mempertanyakan Privasi Di Era Selebgram: Masih Adakah?" Jurnal ILMU KOMUNIKASI 13(2):179. doi: 10.24002/jik.v13i2.682.

Kriyantono, Rachmat. 2014. Teknik Praktis Riset Komunikasi: Disertai Contoh Praktis Riset Media, Public Relations, Advertising, Komunikasi Organisasi, Komunikasi Pemasaran. Jakarta: Kencana Prenadamedia Group.

Levit, Nancy. 1998. The Gender Line. New York: University Press.

Lips, Hillary M. 2017. A New Psychology of Women. Waveland Press.

Misel, Katherine. 2017. "Klipsun Magazine, 2017 , Volume 47 , Issue 02 - Winter WINTER 2017 / FORWARD.” 47(02).

Mulyana, Deddy. 2009. Ilmu Komunikasi Suatu Pengantar. Bandung: PT Remaja Rosdakarya.

Nasrullah, Rulli. 2018. Media Sosial: Persfektif Komunikasi, Budaya, Dan Sosioteknologi. Bandung: Simbiosa Rekatama Media.

Nugraheni, Yuli, and Yuni W. Anastasia. 2017. "Social Media Habit Remaja Surabaya." Jurnal Komunikatif 6(1):13-30.

Nugroho Adi, Tri. 2012. "Mengkaji Khalayak Media Dengan Metode Penelitian Resepsi." Acta Dium A Vol 8 No 1:26-30.

Nurudin. 2017. Pengantar Komunikasi Massa. Jakarta: PT Raja Grafindo Persada.

Pattipeilohy, Esther Meilany. 2015. "Citra Diri Dan Popularitas Artis." Jurnal Kajian Komunikasi 3(1):22-32. doi: 10.24198/jkk.vol3n1.3.

Primada Qurrota Ayun. 2015. "Fenomena Remaja Menggunakan Media Sosial Dalam Membentuk Identitas." Channel, Vol. 3, No. 2, Oktober 2015, Hal. 1-16 3(2):1-16.

Pujileksono, Sugeng. 2016. Penelitian Komunikasi Kualitatif. Malang: Kelompok Intrans Publishing.

Setiadi, Ahmad. 2014. "Pemanfaatan Media Sosial Untuk Efektifitas Komunikasi." Jurnal Ilmiah Matrik 16(1).

Sukendar, Markus Utomo, S. Sos, M. I. Kom Politeknik, and Indonusa Surakarta. 2015. "TATO DAN MEDIA SOSIAL (Studi Tentang MagicInk Dan Kampanye Penggemar Tato Di Media Sosial)." Jurnal Sainstech Politeknik Indonusa Surakarta 2:2355-5009.

Sulaiman, Aimie. 2016. "Memahami Teori Konstruksi Sosial Peter L. Berger." Society 4(1):15-22. doi: 10.33019/society.v4i1.32.

Wibowo, Dwi Edi. 2011. "Peran Ganda Perempuan Dan Kesetaraan Gender." Gender 3(1):356-64. 